\title{
Is nematode colonisation in the presence of Scolelepis in tropical sandy-beach sediment similar to the colonisation process in temperate sandy beaches?
}

\author{
Maria, TF. ${ }^{a, b *}$, Esteves, AM. ${ }^{b}$, Vanaverbeke, J. ${ }^{a}$ and Vanreusel, A. ${ }^{a}$ \\ ${ }^{a}$ Biology Department, Marine Biology Section, Ghent University, Krijgslaan 281 S8, B-9000 Ghent, Belgium \\ bDepartamento de Zoologia, Universidade Federal de Pernambuco - UFPE, Av. Prof. Moraes Rêgo, s/n, \\ Cidade Universitária, CEP 50670-901, Recife, PE, Brazil \\ *e-mail: tatiana.maria@ugent.be
}

Received September 2, 2011 - Accepted March 19, 2012 - Distributed February 28, 2013

(With 6 figures)

\begin{abstract}
The role of a dominant macrobenthic polychaete, Scolelepis squamata, in the colonisation of defaunated tropical sediments by sandy-beach nematodes was investigated and compared with a previous colonisation experiment carried out on a temperate sandy beach. Experimental cylinders, equipped with lateral windows allowing infaunal colonisation, were filled with defaunated sediment containing two treatments, with and without S. squamata. These cylinders were inserted into microcosms containing sediment with indigenous meiofauna collected from the field. The treatments were incubated in the laboratory at ambient temperature and salinity for 7, 14 and 21 days. The nematode assemblages in both treatments did not differ in composition between treatments and from the natural assemblages, suggesting that all the species were equally able to colonise the experimental cores. The presence of the polychaete did not affect the development of the nematode community composition, in contrast to the results from a previous temperate-beach experiment. However, our results did not indicate whether the difference in results was caused by the different behaviour of the polychaete specimens, or by the different composition and response of the present nematode community.
\end{abstract}

Keywords: meiofauna, Scolelepis squamata, Fazenda Beach, microcosm experiment, biological interactions.

\section{A colonização dos sedimentos de praias tropicais por nematódeos na presença de Scolelepis é similar ao processo de colonização que ocorre em praias arenosas temperadas?}

\begin{abstract}
Resumo
Esse estudo avaliou a influência da espécie Scolelepis squamata (Polychaeta) no processo de colonização de sedimentos defaunados obtidos em uma praia arenosa tropical, além de comparar esses resultados com um estudo similar realizado em uma praia temperada. Sedimentos, previamente defaunados, foram colocados em amostradores com aberturas laterais, que permitiram a colonização da meiofauna. Foram definidos dois tratamentos, um com a presença e outro com a ausência da espécie $S$. squamata, além do controle. Os amostradores desses tratamentos foram alocados em unidades experimentais do tipo microcosmo, as quais continham sedimento com a meiofauna residente. Os tratamentos foram incubados em laboratório por 7, 14 e 21 dias, com condições controladas de temperatura e salinidade. Os nematódeos não apresentaram diferenças significativas em termos de composição entre os tratamentos e nem em relação ao controle, sugerindo que todas as espécies desse grupo foram, igualmente, capazes de colonizar as unidades experimentais. Esses resultados indicaram que a presença do poliqueto não afetou a estrutura da comunidade de nematódeos, o que representou um resultado contrário ao obtido para a praia temperada. No entanto, não se pode concluir se essas diferenças entre as praias estariam relacionadas ao comportamento diferencial de $S$. squamata ou pela presença de comunidades de nematódeos distintas nas praias.
\end{abstract}

Palavras-chave: meiofauna, Scolelepis squamata, Praia da Fazenda, experimento de microcosmo, interações biológicas. 


\section{Introduction}

The presence of nematodes as a group in the sediment is independent of the sediment composition (Vanaverbeke et al., 2000), but, in general, nematodes are said to be highly dominant in sand finer than $300 \mu \mathrm{m}$ (McLachlan and Brown, 2006). Several studies have largely demonstrated the importance of sediment characteristics, such as median grain size, silt content and sorting as key aspects structuring the composition and diversity of free-living nematodes (e. g. Wieser, 1959; Ward, 1973; Heip and Decraemer, 1974; Vincx, 1989; Vincx et al., 1990; Vanreusel, 1990; Vanaverbeke et al., 2002, 2011). Then, despite the geographic area or the tidal regime of a sandy beach, the sediment seems to be more important in structuring the nematode community. However, the three-dimensional sediment of sandy beaches is not exclusively inhabited by nematodes; diverse communities including species of different sizes of organisms, such as micro-, meio- (other than nematodes) and macrofauna are also found in sandy beach sediments. These organism group sizes generally interact with each other by means of trophic interactions (Schratzberger and Warwick, 1999; Tita et al., 2000; Aarnio et al., 2001) or non-trophic interactions (Van Colen et al., 2009; Braeckman et al., 2011; Maria et al., 2011) and, therefore, interactions between macrofauna and nematodes also influence the nematode composition of sandy beach sediments (Maria et al., 2011).

Among the macrofauna organisms from medium to very fine sandy beach sediments Scolelepis squamata Müller, 1806 (Polychaeta) is often very abundant in the North and South Atlantic, the North Pacific, the Indian Ocean and the Mediterranean Sea (Souza and Borzone, 2000). It can reach high abundances in the upper intertidal zone (Elliot et al., 1997; Degraer et al., 2003), the midtide level (Knott et al., 1983; Souza and Borzone, 2000; Janssen and Mulder, 2005) or in the subtidal (Knott et al., 1983; Hartmann-Schröeder, 1996; Souza and Borzone, 2000). Recent morphometric studies have shown that this supposedly cosmopolitan species is, rather, a species complex, at least in the South Atlantic, and its members can be distinguished only by a detailed morphological analysis combined with electron microscopy (MacCord and Amaral, 2005; Rocha et al., 2009).

Polychaetes identified as Scolelepis squamata can modify the environment through their burrowing and deposit-feeding activities, and by producing pseudofaeces (Dauer, 1983; Pardo and Amaral, 2004; Van Hoey et al., 2004). In experimental treatments with fauna from an ultradissipative sandy beach at De Panne, North Sea, Belgium, S. squamata was able to facilitate the early establishment of two non-predatory nematode species by inhibiting the continuous colonisation of initially dominant opportunistic nematode species represented only by Enoplolaimus litoralis (Maria et al., 2011). However, the generality of these results is not yet established. While it cannot be excluded that individuals presently attributed to $S$. squamata in different parts of the world are actually different species, it can be assumed that they do share similar behavioural characteristics. Therefore, by conducting nematode colonisation experiments with $S$. squamata in different regions of the world, it can be investigated whether the positive or negative effects of the presence of a dominant macrofaunal species established in temperate, macrotidal beaches (Maria et al., 2011) can be generalised to other beach types in other worldwide regions. Therefore, a laboratory microcosm experiment was set up to test the effect of $S$. squamata on the colonisation of azoic sediments by free-living nematodes in a tropical microtidal sandy beach in Brazil. We specifically tested the null hypothesis that the nematode community in newly colonised sediments is unaffected by the presence of the polychaete, and our results were compared with previously conducted experiments on macrotidal sandy beaches in temperate regions (Maria et al., 2011). The results of this study will (1) increase the knowledge of macrofaunameiofauna interactions in tropical sandy beaches, and (2) allow an assessment of the generality of these patterns across different sandy beaches.

\section{Material and Methods}

\subsection{Study area and sediment sampling}

Sediment from the upper $10 \mathrm{~cm}$ was collected from the upper intertidal level from Praia da Fazenda, a tropical, dissipative sandy beach $\left(44^{\circ} 48^{\prime} \mathrm{W}-44^{\circ} 52^{\prime} \mathrm{W}\right.$ and $23^{\circ}$ $20^{\prime}-23^{\circ} 22^{\prime}$ S) in the Parque Estadual da Serra do Mar, municipality of Ubatuba, São Paulo, Brazil (Figure 1) four weeks prior to the experimental set-up (15 $5^{\text {th }}$ May 2008). The intertidal area is approximately $3.5 \mathrm{~km}$ long, with a mangrove located at the north inlet edge.

\subsection{Experimental set-up}

Sediments previously collected were defaunated and made inorganic by burning to $500{ }^{\circ} \mathrm{C}$ for $4 \mathrm{~h}$ in a muffle furnace. One day before the experimental set-up $\left(19^{\text {th }}\right.$ June 2008), triplicate field control (FC) samples were collected using Perspex corers $\left(10 \mathrm{~cm}^{2}\right)$ to a depth of $10 \mathrm{~cm}$, in order to collect baseline information on the resident nematode community. Then, large volumes of sand were collected from the same area visited on $15^{\text {th }}$ May. This sediment was homogenised in the field by successive rework and taken to the laboratory to fill the microcosm aquaria of $0.24 \mathrm{~m}^{2}$. Scolelepis squamata individuals were sampled by sieving sediment from the upper intertidal level of the beach. They were kept alive until the experimental set-up in an aquarium filled with sand and oxygenated sea water.

Six microcosms, each consisting of a plastic aquarium (72 1), were filled with homogenised sediment inhabited by natural meiofaunal and macrofaunal sandy-beach communities to a depth of $12 \mathrm{~cm}$. The sediments were left untouched for one day, to allow the community to stabilise. One corner $\left(96 \mathrm{~cm}^{2}\right)$ of the aquarium was kept free in order to place a water pump, silicone tubes and air stones in a plastic container, to avoid any disturbance of the sediment. Thirty-six experimental cylinders $\left(10 \mathrm{~cm}^{2}\right)$ were allocated to three types of treatment (see below) and were 


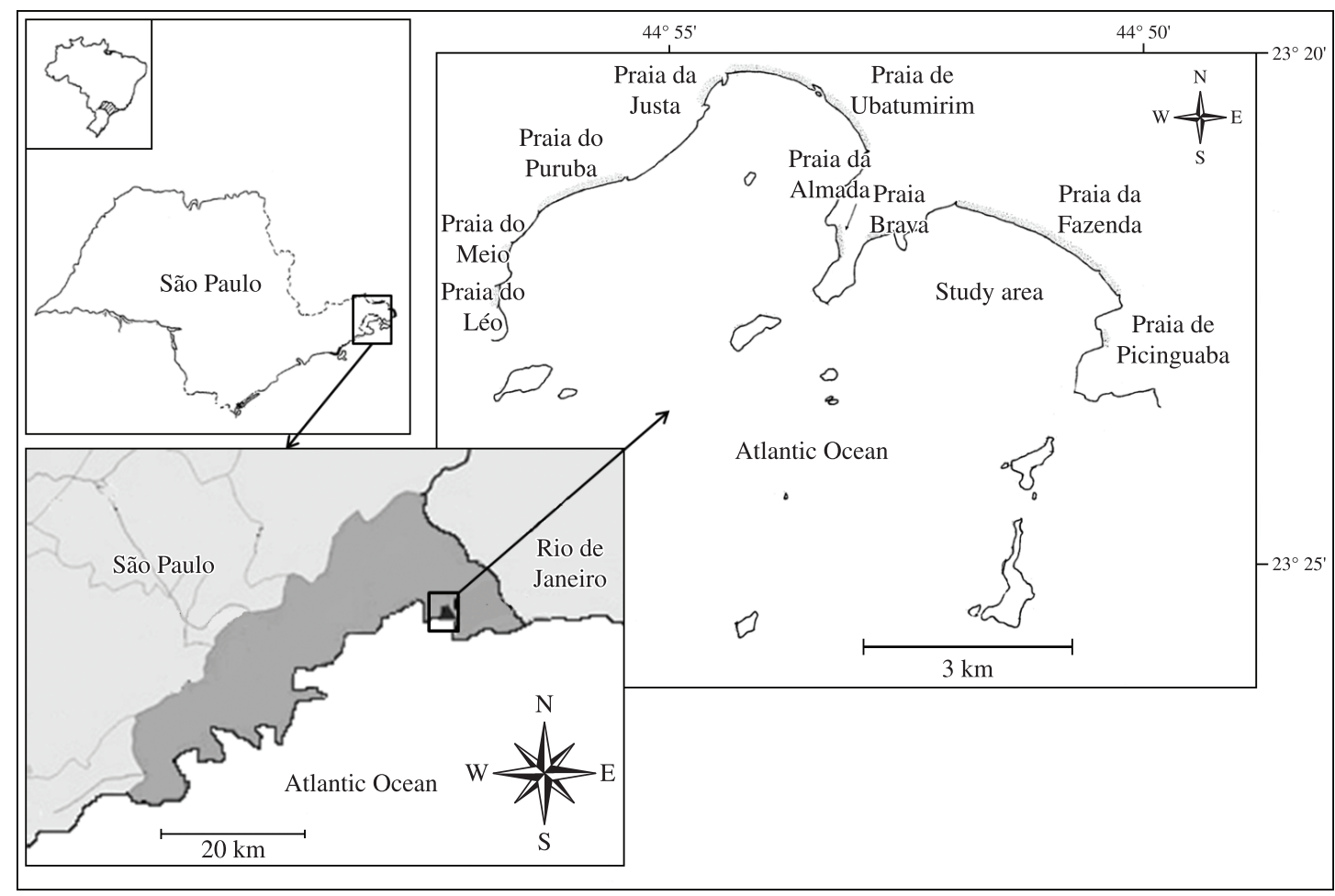

Figure 1. Study area localized in the Parque Estadual da Reserva do Mar at the southeast coast of Brazil.

randomly pushed into the sediment of different aquaria at a regular distance of $10 \mathrm{~cm}$ (Figure 2a). Before the addition of the experimental corers, a similar-sized corer removed the corresponding amount of sediment from the aquarium, in order to reduce disturbance. The experimental corers had two opposite lateral windows, each $5.3 \mathrm{~cm} \times 2.6 \mathrm{~cm}$, covered by gauze with a mesh size of $300 \mu \mathrm{m}$ (Figure $2 \mathrm{~b}$ ). These lateral windows allowed meiofaunal migration from the adjacent sediment. The upper $2 \mathrm{~cm}$ of the gauze was in contact with the water, in order to allow mimicking of tides inside these corers; however, the water level never overtopped the edge of the corers.

Experimental cylinders with three different treatments were randomly distributed in the 6 aquaria. They consisted of:

1. Indigenous control (IC): natural sediment with indigenous community, collected simultaneously with the sediment used to fill the aquarium. This type of control was used to check for a possible effect of the use of the corer;

2. Azoic treatment (AT): defaunated sediment; and

3. Scolelepis treatment (ST): defaunated sediment +5 specimens of $S$. squamata, which corresponded to the size of the polychaetes used in the North Sea experiment.

Immediately after the set-up of the experiment, the sediment in the aquarium was covered with $3.5 \mathrm{~cm}$ filtered seawater of natural salinity (35).

The experiment ran in a temperature-controlled room $\left(25^{\circ} \mathrm{C}\right)$ in a day and night light regime of 12 : 12 . Tides were simulated twice a day, to a maximum water depth of $3.5 \mathrm{~cm}$ above the sediment layer. The water entered into the experimental cylinders through the upper $2 \mathrm{~cm}$ of the gauze, covering the lateral windows of the cylinder. The sediment was submerged for 2 hours and exposed to the air for 10 hours. Changes in salinity of the seawater were monitored daily, and increases due to evaporation were avoided by adding deionised water to the water reservoir, thereby maintaining the natural salinity.

Three replicates of each treatment were removed from different aquaria and transferred into a plastic container at 7, 14, 21 days post-placement during simulated low tide. At the same time, control samples (AQ) were randomly collected using a $10-\mathrm{cm}^{2}$ cylinder. Immediately after the removal of the experimental cylinders, the holes were filled with similar-sized empty corers to prevent the surrounding sediment from collapsing. All samples were preserved in a $10 \%$ formaldehyde solution until sample processing.

\subsection{Sample processing in the laboratory}

After the experiment ended, nematodes were extracted from the sediment by centrifugation with Ludox (Heip et al., 1985). Macrofauna was excluded by means of a 1-mm sieve. All organisms retained on a $38-\mu \mathrm{m}$ sieve were counted and enumerated under a dissecting microscope. A sub-sample of 100 random nematodes were transferred to De Grisse solution (De Grisse, 1969) and mounted on slides for further identification to genus and species. Cylinders from the Scolelepis treatment were checked to assess if the organisms were still alive on the day of the sampling. 


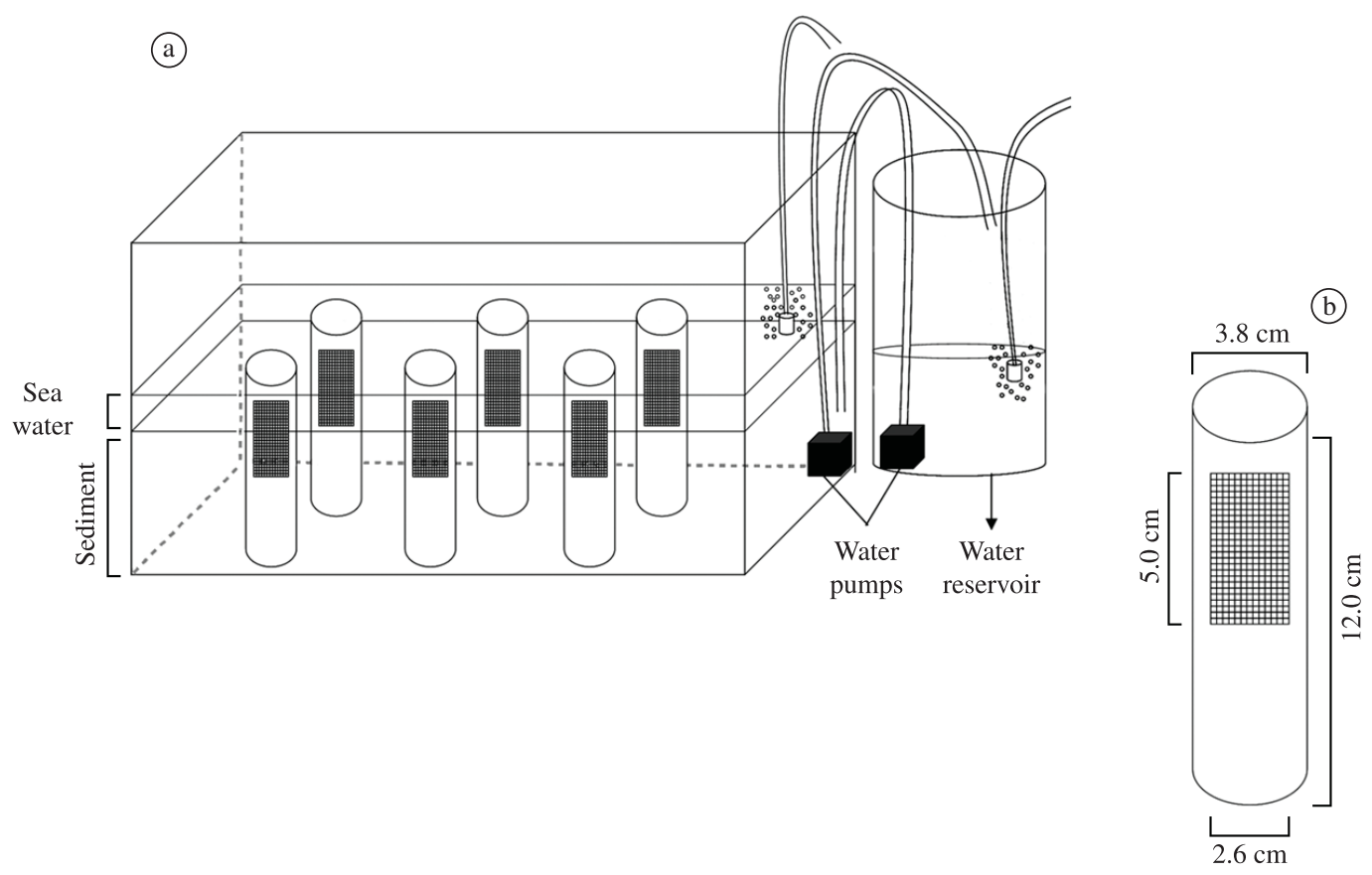

Figure 2. Schematic drawing of the experimental set-up. A: aerated microcosms $(57 \times 37 \times 31 \mathrm{~cm})$, B: syringes with lateral window of $5 \mathrm{~cm} \times 2.6 \mathrm{~cm}$ which were filled with the different types of treatments.

\subsection{Data analyses}

Nematode assemblages from all the treatments and sampling dates were analysed using univariate and multivariate techniques. Total densities per $10 \mathrm{~cm}^{2}$, species richness $(\mathrm{S})$ and diversity (Shannon diversity index $-\mathrm{H}^{\prime}$ $\log _{\mathrm{e}}$ ) were calculated for each treatment.

Differences between nematode densities of FC and $\mathrm{AQ}$, and between FC and IC were analysed by t-tests. Differences in nematode densities among sampling times in AQ and IC were analysed by one-way ANOVA after checking that the necessary assumptions were met.

Experimental effects on total nematode density per $10 \mathrm{~cm}^{2}$, species richness (S) and diversity (H') were tested by two-way analysis of variance (two-way ANOVA). When significant differences were detected, Tukey HSD tests were applied for testing for pairwise differences. Cochran's test was applied to check the homogeneity of the variances. Differences in nematode community structure were analysed by non-metric Multi-Dimensional Scaling (MDS) using the Bray-Curtis Similarity on non-transformed data for each sample. A one-way PERMANOVA was applied to analyse differences in the nematode community structure among FC, AQ and IC; and a two-way design was applied to evaluate differences in the community structure among treatments (AQ, IC, AT and ST) and over time (Anderson et al., 2008). Since a PERMANOVA test can show significant differences between groups, but does not distinguish between a difference due to factor effects or dispersion (variance), homogeneity of multivariate dispersion was tested with PERMDISP, using distances among centroids calculated in the treatment $\times$ time group. The PERMDISP test was never significant, indicating equally dispersed distances to centroids. In case of a significant result in the PERMANOVA design, pairwise tests for the significant term were performed. In cases of restricted number of possible permutations in pairwise tests, $p$-values were obtained from Monte Carlo samplings (Anderson and Robinson, 2003). The species contributing most to within-group similarity were identified by the two-way crossed SIMPER analysis. All the multivariate analyses, and the calculation of S and H' were performed using the PRIMER v6 with PERMANOVA + add on software package (Clark and Gorley, 2006; Anderson et al., 2008), and the t-test and ANOVA were done using STATISTICA 7.0.

\section{Results}

\subsection{Effect on density and diversity of the nematode communities}

The nematode densities recorded in AQ samples were not significantly different from the values recorded from the field samples (time zero) (Figure 3; t-test, $t=-0.49$, $\mathrm{p}=0.65$ ) and did not change significantly over the course of the experiment (Figure 4, one-way ANOVA, $\mathrm{F}_{2,6}=0.94$, $\mathrm{p}=0.44)$. Considering the indigenous controls, the densities were also not statistically different from the field samples (Figure 3; t-test, $\mathrm{t}=0.81, \mathrm{p}=0.46$ ). There was no significant change over time in the densities of IC over the course of the experiment (Figure 4, one-way ANOVA, $\mathrm{F}_{2,6}=0.63, \mathrm{p}=0.57$ ). 
Nematode densities were not affected by treatment or by time, whereas species richness was significantly affected by the time $\times$ treatment interaction term (Table 1, Figure 5). Tukey HSD (Table 1) indicated that these differences were caused by the higher species richness found in AQ at day-7 and in IC at day-14 and day-21. H' diversity was significantly affected by treatment only, since a higher diversity was found at IC (Table 1, Figure 5).

\subsection{Effect on the nematode community composition}

A mean of 16.983 individuals were counted in this study, belonging to 21 species and 2 unidentified genera. Daptonema sp. A, Theristus sp. A, Theristus sp. C, Neochromadora sp., and Nudora besnardi (Gerlach, 1956) were the dominant species in both the field control and experimental treatments (Appendix). The first three species are classified as non-selective deposit feeders and the latter two as epistrate feeders, according to Wieser (1953). No significant differences in nematode community composition were observed among FC, AQ, and IC treatments at the beginning of the experiment (one-way PERMANOVA: Pseudo- $\mathrm{F}_{2.6}=1.92, \mathrm{p}=0.057$ ). In addition, nematode communities from both AQ and IC did not change significantly over time (one-way PERMANOVA;

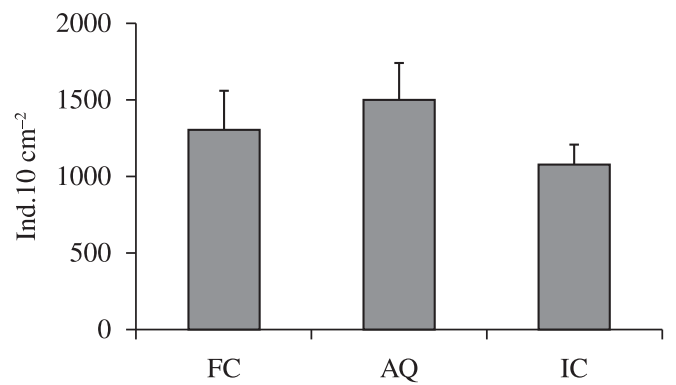

Figure 3. Mean nematode density in the field control $(t=0)$ and in the initial stages of the experiments $(t=7)$. FC: field control, AQ: aquarium control, IC: indigenous control. Error bar represents $\pm \operatorname{SE}(n=3)$. and Pseudo- $\mathrm{F}_{2,6}=1.30, \mathrm{p}=0.253$ and Pseudo- $\mathrm{F}_{2,6}=1.586$, $\mathrm{p}=0.198$, respectively).

Nematode community composition was significantly affected by treatment and time, but not affected by the interaction term (Table 2). The pairwise test showed that the nematode communities from AQ were different from AT, and the nematode communities present at day-7 were significantly different from the communities encountered at day-14 (Figure 6, Table 2).

The species contributing to the similarity within each treatment and time indicated by two-way crossed SIMPER are listed in Table 3. Within-group similarity in AQ and IC was mainly determined by Daptonema sp. A and Nudora besnardi, whereas Daptonema sp. A and Theristus sp. A were much more important in AT. The difference between day-7 and day-14 mainly occurred by the replacement of the dominant Theristus sp. C by Theristus sp. A on the latter sampling day (Table 3).

\section{Discussion}

\subsection{Experimental set-up}

Initial changes in nematode densities, diversity and community composition caused by manipulation of the

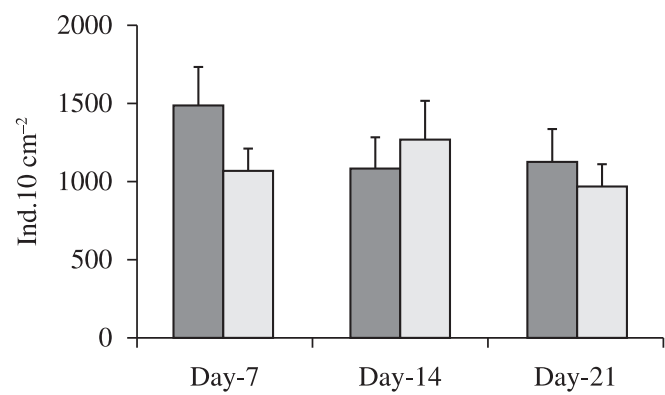

Figure 4. Mean nematode density in the controls over the 21 days of the experiment. Black bars represent AQ and grey bars represent IC. Error bar shows \pm SE $(n=3)$.

Table 1. Results from two-way ANOVA for the treatment and time effects on nematodes univariate measurements and overview of the Tukey HSD-test for number of species and Shannon diversity. Field controls are not included in this analysis.

\begin{tabular}{|c|c|c|c|c|c|c|}
\hline \multirow{2}{*}{ ANOVA } & \multicolumn{2}{|c|}{ Treatment } & \multicolumn{2}{|c|}{ Time } & \multicolumn{2}{|c|}{ Treatment $\times$ Time } \\
\hline & $\mathbf{F}_{(3,24)}$ & $\mathbf{p}$ & $\mathbf{F}_{(2,24)}$ & $\mathbf{p}$ & $\mathbf{F}_{(6,24)}$ & $\mathbf{p}$ \\
\hline Density & 0.79 & 0.507 & 2.68 & 0.089 & 2.06 & 0.096 \\
\hline Species richness $(\mathrm{S})$ & 23.18 & $<0.001 *$ & 0.25 & 0.805 & 3.18 & $0.019 *$ \\
\hline Diversity (H') & 11.36 & $<0.001 *$ & 2.54 & 0.100 & 0.99 & 0.448 \\
\hline Groups compared & \multicolumn{3}{|c|}{ Result for $\mathrm{S}$} & \multicolumn{3}{|c|}{ Result for H' } \\
\hline $\mathrm{AQ} \times \mathrm{IC}$ & \multicolumn{3}{|c|}{ no difference } & \multicolumn{3}{|c|}{$\mathrm{AQ}<\mathrm{IC}$} \\
\hline $\mathrm{AQ} \times \mathrm{AT}$ & \multicolumn{3}{|c|}{ no difference } & \multicolumn{3}{|c|}{ no difference } \\
\hline $\mathrm{AQ} \times \mathrm{ST}$ & \multicolumn{3}{|c|}{ day 7 (ST < AQ) } & \multicolumn{3}{|c|}{ no difference } \\
\hline $\mathrm{IC} \times \mathrm{AT}$ & \multicolumn{3}{|c|}{ day $14,21(\mathrm{IC}>\mathrm{AT})$} & \multicolumn{3}{|c|}{$\mathrm{IC}>\mathrm{AT}$} \\
\hline $\mathrm{IC} \times \mathrm{ST}$ & \multicolumn{3}{|c|}{ day 14,21 (IC > ST) } & \multicolumn{3}{|c|}{$\mathrm{IC}>\mathrm{ST}$} \\
\hline $\mathrm{AT} \times \mathrm{ST}$ & \multicolumn{3}{|c|}{ no difference } & \multicolumn{3}{|c|}{ no difference } \\
\hline
\end{tabular}

AQ: aquarium control, IC: indigenous control, AT: azoic treatment, ST: Scolelepis treatment. *: significant values 

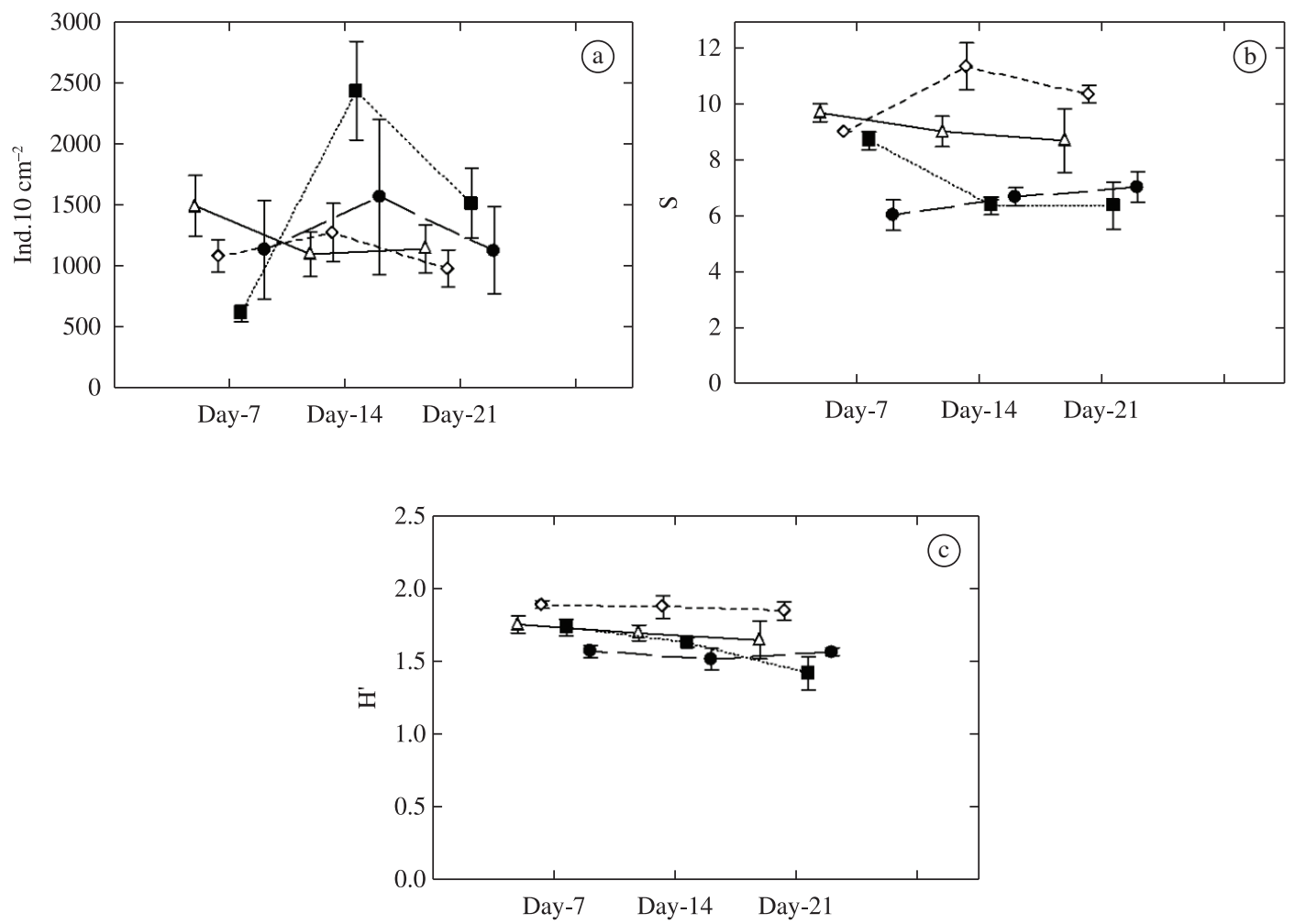

Figure 5. Univariate indices for nematode assemblages over the 21 days of the experiment. Treatment results (black symbols) were plotted against data obtained for the laboratory controls - AQ and IC - (open symbols) that served as potential species pool for colonisation of the defaunated sediment. a) mean total nematode density, b) species richness (S), c) Shannon diversity index $\left(H^{\prime}\right)$. Error bar represents $\pm \mathrm{SE}(\mathrm{n}=3)$. AQ: triangles, IC: diamonds, AT: squares, ST: circles.

Table 2. Results from two-way PERMANOVA using BrayCurtis similarity on non-transformed data showing the effect of treatment and time on nematode community and results from pair-wise tests using Bray-Curtis similarity on non-transformed, showing the treatment and time effect on nematode communities. Abbreviations as used in Table 1.

\begin{tabular}{lccl}
\hline \multicolumn{1}{c}{ Factors } & MS & Pseudo-F & \multicolumn{1}{c}{$\mathbf{p}$} \\
\hline Treatment $_{(3,24)}$ & 1382 & 2.06 & $0.022^{*}$ \\
Time $_{(2,24)}$ & 2066 & 3.07 & $0.007^{*}$ \\
treatment $\times$ time $_{(6,24)}$ & 1109 & 1.65 & 0.067 \\
\hline Groups of treatments $^{2}$ & $\mathrm{~T}$ & $\mathrm{p}$ \\
\hline $\mathrm{AQ} \times \mathrm{IC}$ & 0.97 & 0.437 \\
$\mathrm{AQ} \times \mathrm{AT}$ & 1.84 & $0.014^{*}$ \\
$\mathrm{AQ} \times \mathrm{ST}$ & 1.44 & 0.100 \\
$\mathrm{IC} \times \mathrm{AT}$ & 1.92 & $0.020^{*}$ \\
$\mathrm{IC} \times \mathrm{ST}$ & 1.43 & 0.123 \\
$\mathrm{AT} \times \mathrm{ST}$ & 0.99 & 0.396 \\
Groups of days & & \\
\hline $7 \times 14$ & 1.91 & $0.026^{*}$ \\
$7 \times 21$ & 1.68 & $0.037^{*}$ \\
$14 \times 21$ & 1.65 & 0.055 \\
\hline
\end{tabular}

sediment could not be detected by our experimental design. In addition, no temporal changes were observed over the course of the experiment in AQ, again suggesting that using relatively large microcosms in meiofaunal experimental work avoids experimental artefacts (Maria et al., 2011). The absence of changes in density and nematode composition in the IC shows that cage effects did not occur in our experiment.

\subsection{Colonisation pattern}

A similar colonisation pattern was observed between azoic and Scolelepis treatments in terms of density, diversity and community structure. The nematode colonisation was a very rapid process, and all species had the same ability to colonise the newly available sediment since many of the species found in the source community (AQ) were found in the colonising cores (AT and ST). Previous colonisation experiments have shown that the success of a certain nematode genus, such as Sabatieria (Schratzberger et al., 2004), Leptolaimus (Gallucci et al., 2008) and Enoplolaimus (Maria et al., 2011), in colonising abundantly a new area is attributed to their relatively large body size. Our source community (AQ) lacked those large nematodes, mainly 
Table 3. Output of two-way crossed SIMPER analysis showing the top 50\% typical species for each treatment.

\begin{tabular}{|c|c|c|c|c|c|c|c|}
\hline \multirow{2}{*}{ Species } & \multicolumn{4}{|c|}{ Treatments } & \multicolumn{3}{|c|}{ Days } \\
\hline & Aquarium & Indigenous & Azoic & Scolelepis & 7 & 14 & 21 \\
\hline Daptonema sp. A & 32 & 24 & 28 & - & 20 & 23 & 36 \\
\hline Nudora besnardi & 23 & 23 & - & 25 & 22 & 26 & - \\
\hline Theristus sp. A & - & 15 & 24 & 29 & - & 24 & 21 \\
\hline Theristus sp. C & - & - & - & - & 21 & - & - \\
\hline Overall similarities & 66 & 70 & 73 & 56 & 68 & 62 & 66 \\
\hline
\end{tabular}

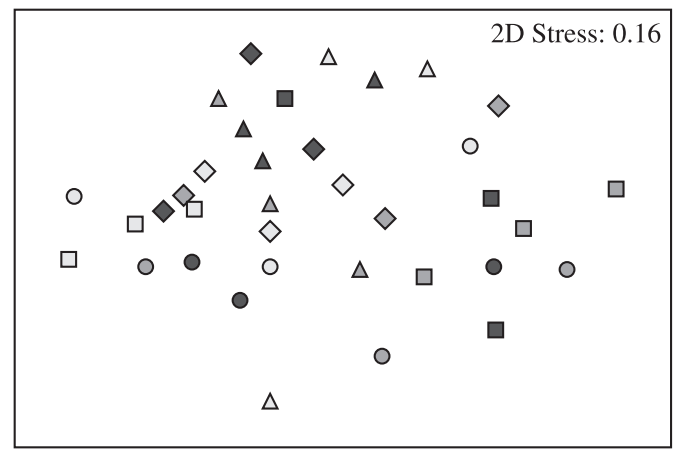

Figure 6. Non-parametric multi-dimensional scaling ordination based non- transformed species density using Bray-Curtis similarity comparing nematode community among lab controls (AQ: triangles, IC: diamonds) and treatments (AT: squares, ST: circles) over time (day-7: light grey, day-14: dark grey; day-21: black).

reflecting the granulometric characteristics of the studied beach since thin nematodes are more prone to occur in very fine sand (Fleeger et al., 2011).

The dominance of Xyalidae and the low number of nematode species also reflect the sediment grain size of Fazenda beach. A high abundance of Xyalidae in sandy beaches composed of fine-grained sediments was already evidenced by Gheskiere et al. (2004), Hourston et al. (2005) and Gourbault and Warwick (1994). In addition, fine sediment has a low diversity of nematodes and is generally inhabited by non-selective deposit feeders (Vanaverbeke et al., 2011), which includes members of Xyalidae.

Although density, diversity and community structure were not significant different, differences were found in terms of species richness. At day 7, a significant difference was found between ST and AQ, which may indicate that the chemical unattractiveness of the sediment is a barrier for the survival of successful rapid-colonising species (Maria et al., 2011). After day 7, there was a slight but significant rise in species richness in ST, indicating that environmental conditions had improved. Similar observations were made in temperate beaches (Maria et al., 2011) and were attributed to the recovery of microbial communities after defaunation (Stocum and Plante, 2006).
No significant differences in terms of density, diversity and nematode community composition were found between the azoic and the Scolelepis treatment, in contrast to the findings obtained for a temperate, macrotidal sandy beach (Maria et al., 2011). In the latter study, a significant difference in the diversity between AT and ST was observed, attributable to the ability of $S$. squamata to inhibit the initially high colonisation rates of an opportunistic, largesized predatory nematode, Enoplolaimus litoralis Schulz, 1936. A similarly prominent, predatory nematode was not present in the experimental and natural communities of the tropical Brazilian beach. Although Nudora besnardi and Neochromadora sp. both have an armed buccal cavity with sclerotised teeth and/or denticles, their buccal cavity is mainly adapted to pierce diatoms and/or scrape sand particles (Moens and Vincx, 1997). Nudora besnardi can also be relatively large in size $(0.9-1 \mathrm{~mm})$, but will never attain the large size of E. litoralis (1.4-2.5 mm), to which its high mobility and high colonisation rate in the beginning of the experiment was attributed (Maria et al., 2011). Therefore, the discrepancy between the results obtained here and the previous colonisation experiment may be a consequence of different nematode communities in both geographic areas which reflect directly the sediment composition of both areas.

The absence of interactions between nematodes and the polychaete could also be due to the species of polychaete used in our experiment. The species used here belongs to a species complex that includes $S$. squamata, S. chilensis and S. goodbodyi (Rocha et al., 2009). These species differ among each other in small morphological details, such as the shape of the notopodial lamellae and their fusion with gills (Rocha et al., 2009). Few studies have focused on the biology and ecology of these species (Hernandez et al., 2008; MacCord and Amaral, 2005, 2007), but our results might indicate that species that are so closely related can show different behaviours in the sediment. However, further testing is necessary to resolve the question of whether the divergent results between this experiment and the previous experiment with North Sea fauna (Maria et al., 2011) might be related to differences in the nematode community composition or to differences in the behaviour of, perhaps, different members of the $S$. squamata-group in the colonisation process.

Acknowledgements - We are thankful to Adriane Wandeness, Claudio Bloise and Márcio Macedo for their help during the 
sampling and transport of the sediment, as well as Sérgio Bonecker and Ana Bonecker for providing the experimental room facilities of their laboratory. We thank Dr. Janet W. Reid, JWR Associates, for her critical revision of the English. The reviewer is also acknowledged for her comments in an earlier version of the manuscript. The first author was sponsored by a Ph.D. scholarship from Vlaamse Interuniversitaire Raad - VLIR-UOS. This paper contributes to FWO project G.0041.08N.

\section{References}

AARNIO, K., 2001. The role of meiofauna in benthic food webs of the northern Baltic Sea. Acta Academiae Aboensies, vol. 61B, p. 1-37.

ANDERSON, MJ. and ROBINSON, J., 2003. Generalized discriminant analysis based on distances. Australian and New Zealand Journal of Statistics, vol. 45, no. 3, p. 301-318. http:// dx.doi.org/10.1111/1467-842X.00285

ANDERSON, MJ., GORLEY, RN. and CLARKE, KR., 2008. PERMANOVA+ for PRIMER: guide to software and statistical methods. Plymouth: PRIMER-E. 274p.

BRAECKMAN, U., VAN COLEN, C., SOETAERT, K., VINCX, M. and VANAVERBEKE, J., 2011. Contrasting macrobenthic activities differentially affect nematode density and diversity in a shallow subtidal marine sediment. Marine Ecology Progress Series, vol. 422, no. 1, p. 179-191. http://dx.doi.org/10.3354/meps08910

CLARK, K. and GORLEY, RN., 2006. Primer v6: User Manual/ Tutorial. Plymouth: PRIMER-E.

DAUER, DM., 1983. Functional morphology and feeding behavior of Scolelepis squamata (Polychaeta: Spionidae). Marine Biology, vol. 77, no. 3, p. 279-285. http://dx.doi.org/10.1007/BF00395817

DE GRISSE, AT., 1969. Redescription ou modification de quelques techniques utilisés dans l'études dês nématodes phytoparaires. Mededelingen Rijksfakulteit Landbouwwetenschappen Gent, vol. 34, p. 351-369.

DEGRAER, S., VOLCKAERT, A. and VINCX, M., 2003. Macrobenthic zonation patterns along a morphodynamical continuum of macrotidal, low tide bar/rip and ultra-dissipative sandy beaches. Estuarine, Coastal and Shelf Science, vol. 56, no. 3, p. 459-468. http://dx.doi.org/10.1016/S0272-7714(02)00195-6

ELLIOT, B., DEGRAER, S., BURSEY, M. and VINCX, M., 1997. Intertidal zonation of macrofauna on a dissipative, sandy beach at De Panne (Belgium): a pilot study. Biologisch Jaarboek Dodonaea, vol. 64 , p. 92-108.

FLEEGER, JW., GRIPPO, MA. and PASTORICK, ST., 2011. What is the relative importance of sediment granulometry and vertical gradients to nematode morphometrics? Marine Biology Research, vol. 7, no. 2, p. 122-134. http://dx.doi.org/10.1080/1 7451000.2010 .492221

GALLUCCI, F., MOENS, T., VANREUSEL, A. and FONSECA, G., 2008 Active colonisation of disturbed sediments by deepsea nematodes: evidence for the patch mosaic model. Marine Ecology Progress Series, vol. 367, no. 1, p. 173-183. http://dx.doi. org/10.3354/meps07537

GHESKIERE, T., HOSTE, E., VANAVERBEKE, J., VINCX, M. and DEGRAER, S., 2004. Horizontal zonation patterns and feeding structure of marine nematode assemblages on a macrotidal, ultra-dissipative sandy beach De Panne, Belgium. Journal of Sea
Research, vol. 52, no. 3, p. 221-226. http://dx.doi.org/10.1016/j. seares.2004.02.001

GOURBAULT, N. and WARWICK, RM., 1994 Is the Determination of Meiobenthic Diversity Affected by the Sampling Method in Sandy Beaches? Marine Ecology, vol. 15, no. 3, p. 267-279. http:// dx.doi.org/10.1111/j.1439-0485.1994.tb00057.x

HARTMANN-SCHRÖEDER, G., 1996. Annelida. Borstenwürmer, Polychaeta - Tierwelt Deutschlands Teil 58. Jena: Gustav Fischer Verlag. 648 p.

HEIP, C. and DECRAEMER, W., 1974. The diversity of nematode communities in the southern North Sea. Journal of the Marine Biological Association of the United Kingdom, vol. 54, no. 1, p. 251-255. http://dx.doi.org/10.1017/S0025315400022189

HEIP, C., VINCX, M. and VRANKEN, G., 1985 The ecology of Marine Nematodes. Oceanography and Marine Biology: An Annual Review, vol. 23, p. 399-489.

HERNANDEZ, C., CONTRERAS, SH., GALLARDO, JA. and CANCINO, JM., 2008. Community structure of the macroinfauna along of a sandy beach of central Chile: Lenga, Bahia San Vicente. Revista Chilena de Historia Natural, vol. 71, no. 3, p. 303-311.

HOURSTON, M., WARWICK, RM., VALESINI, FJ. and POTTER, IC., 2005. To what extent are the characteristics of nematode assemblages in nearshore sediments on the west Australian coast related to habitat type, season and zone? Estuarine, Coastal and Shelf Science, vol. 64, no. 4, p. 601-612. http://dx.doi.org/10.1016/j. ecss.2005.04.001

JANSSEN, G. and MULDER, S., 2005. Zonation of macrofauna across sandy beaches and surf zone along the Dutch coast. Oceanologia, vol. 47, no. 2, p. 265-282.

KNOTT, DM., CALDER, DR. and VAN DOLAH, RF., 1983. Macrobenthos of sandy beach and nearshore environments at Murrels Inlet, South Carolina, U.S.A. Estuarine Coastal and Shelf Science, vol. 16, no. 5, p. 573-590. http://dx.doi.org/10.1016/02727714(83)90087-2

MacCORD, FS. and AMARAL, ACZ., 2005. Morphometric analyses of two species of Scolelepis (Polychaeta: Spionidae). Journal of the Marine Biological Association of the United Kingdom, vol. 85, no. 4, p. 829-834. http://dx.doi.org/10.1017/ S002531540501177X

MacCORD, FS. and AMARAL, ACZ., 2007. The reproductive cycle of Scolelepis goodbodyi (Polychaeta: Spionidae). Marine Biology, vol. 151, no. 3, p. 1009-1020. http://dx.doi.org/10.1007/ s00227-006-0540-9

MARIA, TF., ESTEVES, AM., VANAVERBEKE, J. and VANREUSEL, A., 2011. The effect of the dominant polychaete Scolelepis squamata on nematode colonisation in sandy beach sediments: an experimental approach. Estuarine Coastal and Shelf Science, vol. 94, no. 3, p. 272-280. http://dx.doi.org/10.1016/j. ecss.2011.07.006

McLACHLAN, A. and BROWN, A., 2006. The ecology of sandy shores. Elsevier. 373 p.

MOENS, T. and VINCX, M., 1997. Observations on the feeding ecology of estuarine nematodes. Marine Biological Association of the United Kingdom, vol. 77, no. 1, p. 211-227. http://dx.doi. org/10.1017/S0025315400033889

PARDO, EV. and AMARAL, ACZ., 2004. Feeding behavior of Scolelepis sp. (Polychaeta: Spionidae). Brazilian Journal of Oceanography, vol. 52, no. 1, p. 75-79. 
ROCHA, MB., RADASHEVSKY, V. and PAIVA, PC., 2009. Espécies de Scolelepis (Polychaeta, Spionidae) de praias do Estado do Rio de Janeiro, Brasil. Biota Neotropica, vol. 9, no. 4, p. 101-108. http://dx.doi.org/10.1590/S1676-06032009000400012

SCHRATZBERGER, M. and WARWICK, RM., 1999. Impact of predation and sediment disturbance by Carcinus maenas (L.) on free-living nematode community structure. Journal of Experimental Marine Biology and Ecology, vol. 235, no. 2, p. 255-271. http:// dx.doi.org/10.1016/S0022-0981(98)00165-8

SCHRATZBERGER, M., WHOMERSLEY, P., WARR, K., BOLAM, SG. and REES, HL., 2004. Colonisation of various types of sediment by estuarine nematodes via lateral infaunal migration: a laboratory study. Marine Biology, vol. 145, no. 1, p. 69-78. http://dx.doi.org/10.1007/s00227-004-1302-1

SOUZA, JRB. and BORZONE, CA., 2000. Population dynamics and secondary production of Scolelepis squamata (Polychaeta: Spionidae) in an exposed sandy beach of Southern Brazil. Bulletin of Marine Science, vol. 67, no. 1, p. 103-111.

STOCUM, ET. and PLANTE, CJ., 2006. The effect of artificial defaunation on bacterial assemblages of intertidal sediments. Journal of the Marine Biological Association of United Kingdom, vol. 337 , no. 2, p. 147-158.

TITA, G., DESROSIERS, G., VINCX, M. and NOZAIS C., 2000. Predation and sediment disturbance effects of the intertidal polychaete Nereis virens (Sars) on associated meiofaunal assemblages. Journal of Experimental Marine Biology and Ecology, vol. 243, no. 2, p. 261- 282. http://dx.doi.org/10.1016/S0022-0981(99)00116-1

VAN COLEN, C., MONTSERRAT, F., VERBIST, K., VINCX, M., STEYAERT, M., VANAVERBEKE, J., HERMAN, PMJ., DEGRAER, S. and YSEBAERT, T., 2009. Tidal flat nematode response to hypoxia and subsequent macrofauna-mediated alterations of sediment properties. Marine Ecology Progress Series, vol. 381, no. 1, p. 189-197. http://dx.doi.org/10.3354/meps07914

VANAVERBEKE, J., GHESKIERE, T. and VINCX, M., 2000. The meiobenthos of subtidal sandbanks on the Belgian Continental Shelf (Southern Bight of the North Sea). Estuarine Coastal and Shelf Science, vol. 51, no. 5, p. 637-649. http://dx.doi.org/10.1006/ ecss.2000.0703
VANAVERBEKE, J., GHESKIERE, T., STEYAERT, M. and VINCX, M., 2002. Nematode assemblages from subtidal sandbanks in the Southern Bight of the North Sea: effect of small sedimentological differences. Journal of Sea Research, vol. 48, no. 3, p. 197-207. http://dx.doi.org/10.1016/S1385-1101(02)00165-X

VANAVERBEKE, J., MERCKX, B., DEGRAER, S. and VINCX, M., 2011. Sediment-related distribution patterns of nematodes and macrofauna: Two sides of the benthic coin? Marine Environmental Research, vol. 71, no. 1, p. 31-40. PMid:20974491. http://dx.doi. org/10.1016/j.marenvres.2010.09.006

VANREUSEL, A., 1990. Ecology of the free-living marine nematodes from Voordelta (Southern Bight of the North Sea). I. Species composition and structure of nematode communities. Cahiers de Biologie Marine, vol. 31, p. 439-462.

VAN HOEY, G., DEGRAER, S. and VINCX, M., 2004. Macrobenthic community structure of soft-bottom sediments at the Belgian Continental Shelf. Estuarine, Coastal and Shelf Science, vol. 59, no. 04, p. 599-613. http://dx.doi.org/10.1016/j. ecss.2003.11.005

VINCX, M., 1989. Free-living marine nematodes from the Southern Bight of the North Sea. Academiae Analecta, vol. 51, p. 38-70.

VINCX, M., MEIRE, P. and HEIP, C., 1990. The distribution of the nematodes communities in the southern Bight of the North Sea. Cahiers de Biologie Marine, vol. 31, p. 107-129.

WARD, AR., 1973. Studies on the sublittoral free-living nematodes of Liverpool Bay. I. The structure and distribution of the nematode populations. Marine Biology, vol. 22, no. 1, p. 53-66. http://dx.doi. org/10.1007/BF00388910

WIESER, W., 1953. Die Beziehung zwischen Mundhöhlengestalt, Ernährungsweise und Vorkommen bei freilebenden marinen Nematoden. Arkives für Zoologische, vol. 4, p. 439-484.

- 1959. The effect of grain size on the distribution of small invertebrates inhabiting the beaches of Puget Sound. Limnology and Oceanography, vol. 4, no. 2, p. 181-194. http://dx.doi. org/10.4319/lo.1959.4.2.0181 


\section{Appendix}

Appendix 1. Mean total density of the nematode species per $10 \mathrm{~cm}^{2}$ within each treatment at each specific sampling time.

\begin{tabular}{|c|c|c|c|c|c|c|c|c|c|c|c|c|c|}
\hline \multirow{2}{*}{ Species } & \multicolumn{5}{|c|}{ Day-7 } & \multicolumn{4}{|c|}{ Day-14 } & \multicolumn{4}{|c|}{ Day-21 } \\
\hline & FC & $\mathbf{A Q}$ & IC & AT & ST & AQ & IC & AT & ST & AQ & IC & AT & ST \\
\hline Ascolaimus sp. & 0 & 0 & 0 & 0 & 0 & 0 & 13 & 0 & 0 & 0 & 0 & 0 & 0 \\
\hline Bolbolaimus sp. & 0 & 0 & 0 & 0 & 0 & 0 & 5 & 0 & 0 & 0 & 0 & 0 & 0 \\
\hline Cobbia sp. & 0 & 24 & 0 & 5 & 0 & 13 & 11 & 0 & 9 & 6 & 20 & 0 & 6 \\
\hline Daptonema sp.A & 440 & 431 & 252 & 123 & 166 & 253 & 346 & 637 & 236 & 316 & 334 & 494 & 271 \\
\hline Daptonema sp.B & 86 & 79 & 65 & 2 & 0 & 32 & 32 & 0 & 0 & 46 & 47 & 13 & 3 \\
\hline Daptonema sp.C & 6 & 0 & 0 & 4 & 0 & 0 & 5 & 58 & 0 & 0 & 0 & 13 & 0 \\
\hline Dichromadora sp. & 3 & 0 & 0 & 0 & 0 & 0 & 0 & 0 & 0 & 0 & 0 & 0 & 0 \\
\hline Marylynnia sp. & 222 & 77 & 17 & 14 & 10 & 17 & 46 & 0 & 2 & 8 & 3 & 0 & 0 \\
\hline Neochromadora sp. & 50 & 70 & 187 & 53 & 198 & 85 & 101 & 465 & 176 & 93 & 92 & 304 & 187 \\
\hline Nudora besnardi & 243 & 250 & 199 & 156 & 409 & 286 & 471 & 389 & 314 & 392 & 197 & 89 & 149 \\
\hline Odontophora sp. & 11 & 8 & 6 & 0 & 0 & 0 & 11 & 0 & 0 & 3 & 2 & 0 & 0 \\
\hline Paracyatholaimus sp. & 3 & 0 & 0 & 0 & 0 & 7 & 0 & 0 & 23 & 3 & 39 & 0 & 5 \\
\hline Pseudosteineria sp. & 0 & 3 & 8 & 8 & 2 & 0 & 13 & 0 & 0 & 0 & 0 & 6 & 6 \\
\hline Pselionema sp. & 6 & 6 & 0 & 0 & 0 & 0 & 0 & 0 & 0 & 0 & 6 & 0 & 0 \\
\hline Sabatieria sp. & 35 & 19 & 31 & 0 & 0 & 6 & 51 & 14 & 0 & 27 & 20 & 6 & 12 \\
\hline Scaptrella sp. & 0 & 6 & 0 & 0 & 0 & 0 & 0 & 0 & 0 & 0 & 0 & 0 & 0 \\
\hline Thalassironus sp. & 8 & 0 & 0 & 0 & 0 & 0 & 0 & 0 & 4 & 0 & 0 & 0 & 3 \\
\hline Theristus sp.A & 141 & 179 & 158 & 108 & 192 & 225 & 308 & 552 & 571 & 143 & 105 & 434 & 372 \\
\hline Theristus sp.B & 19 & 0 & 0 & 0 & 0 & 5 & 0 & 0 & 0 & 0 & 0 & 0 & 0 \\
\hline Theristus sp.C & 31 & 329 & 149 & 127 & 148 & 151 & 193 & 310 & 219 & 94 & 103 & 147 & 106 \\
\hline Theristus sp.D & 0 & 0 & 0 & 0 & 0 & 3 & 0 & 0 & 0 & 0 & 0 & 0 & 0 \\
\hline Non-identified genera & 3 & 0 & 5 & 0 & 0 & 0 & 0 & 0 & 0 & 0 & 0 & 0 & 0 \\
\hline
\end{tabular}

AQ: aquarium control, IC: indigenous control, AT: azoic treatment, ST: Scolelepis treatment. 